\title{
POLITICAL WILL TERHADAP KELEMBAGAAN KPK ERA PRESIDEN JOKOWI
}

Muhammad Ilham Akbar

Universitas Islam Indonesia (UII) Sleman Yogyakarta, Indonesia

Email: memoparase@gmail.com

\section{Abstract}

President Joko Widodo's political will will greatly determine the slowness and speed of the Corruption eradication commission. The problems raised in this research are, first, how Is The political will towards the KPK Institution during the era of President Jokowi. Second, how should President Joko Widodo's political will towards the KPK institutions be? This study aims to find and formulate the necessity of President Joko Widodo's political will for the sustainability of the KPK institutions. The legal research method used in this study is a normative juridical research method, based on primary and secondary legal materials. This study concludes that the political will of President Joko Widodo towards the KPK institutions is still far from what is aspired to. President Joko Widodo's political will should be realized in the form of policies that support the strengthening of the KPK Institution.

Keywords: political will; KPK institution; president jokowi

\begin{abstract}
Abstrak
Political will Presiden Jokowi akan sangat menentukan lambat dan lajunya komisi pemberantasan korupsi. Permasalahan yang diangkat dalam penelitian ini, pertama, Bagaimanakah political will terhadap Kelembagaan KPK era Presiden Jokowi. Kedua, bagaimanakah seharusnya political will Presiden Jokowi terhadap kelembagaan KPK? Penelitian ini bertujuan untuk menemukan dan memformulasikan keharusan politicall will Presiden Jokowi terhadap keberlangsungan kelembagaan KPK. Metode penelitian hukum yang digunakan dalam penelitian ini adalah metode penelitian yuridis-normative, didasarkan pada bahan hukum primer dan sekunder. Penelitian ini menyimpulkan bahwa political will Presiden Jokowi terhadap kelembagaan KPK masih jauh dari yang dicitacitakan. Harusnya political will Presiden Jokowi diwujudkan dalam bentuk kebijakan-kebijakan yang mendukung penguatan terhadap kelembagaan KPK.
\end{abstract}

Kata Kunci: political will; kelembagaan KPK; Presiden Jokowi

\section{Pendahuluan}

Banyak sekali komentar negatif bahkan umpatan-umpatan terhadap perilaku dan pelaku tindak pidana korupsi. Muak, jengkel, gregetan, putus asa, marah, dan hal-hal negatif lain atas langgeng dan menjamurnya perilaku korupsi. Terlebih dalam tayangan televisi, tersangka, terdakwa, dan bahkan terpidana seakan-akan menunjukkan show of

$\begin{array}{ll}\text { How to cite: } & \text { Akbar, Muhammad Ilham (2021) Political Will Terhadap Kelembagaan Kpk Era Presiden Jokowi, } \\ & \text { 3(6). https://doi.org/10.36418/syntax-idea.v3i6.1273 } \\ \text { E-ISSN: } & 2684-883 X \\ \text { Published by: } & \text { Ridwan Institute }\end{array}$


force ataupun berperilaku sebagai celebrity (Waluyo, 2017). Ini merupakan fenomena dimana korupsi seakan menjadi hal yang biasa.

Perilaku korupsi merupakan perbuatan negatif, perlu diberantas pemerintah sebagai ujung tombak pemberantasan korupsi. Dukungan politik pemerintah (presiden), menjadi suatu catatan pasti dalam pemberantasan korupsi (Yuwanto, 2016). Cerita kisah sukses negara yang mampu bangkit dari keterpurukan akibat korupsi umumnya dimulai dari sebuah komitmen (Damanik et al., 2010). pemimpinnya yang kemudian diturunkan dalam berbagai kebijakan politik (Fariz, 2019). Lazimnya dukungan tersebut diberikan terhadap kelembagaan yang melaksanakan pemberantasan korupsi. Berbicara dalam potret Indonesia, maka dukungan tersebut dilihat dari bagaimana seorang Presiden mendukung segala upaya pemberantasan korupsi yang dilakukan oleh KPK, sebagai anak kandung reformasi. Komitmen politik Presiden tersebut jamak dipahami menjadi parameter untuk melihat kehendak baik Presiden (political will) di wilayah pemberantasan korupsi. Kebijakan mendukung KPK dalam pemberantasan korupsi merupakan wujud nyata political will seorang Presiden.

Salah satu political will yang menarik untuk kita bicarakan dalam konteks mendukung KPK dalam pemberantasan korupsi, adalah era Presiden Jokowi. Di awal pemerintahannya Presiden Jokowi dengan tegas secara eksplisit dalam nawa-citanya (Nomenklatur visi-misi Jokowi-JK ditahun 2014) menyebutkan bahwa pemerintahannya kelak menolak negara lemah dengan melakukan reformasi sistem dan penegakan hukum yang bebas korupsi, bermartabat, dan terpercaya. Namun itu merupakan visi-misi, bukan tahapan implementasi. Untuk melihat sejauh mana implementasi visi-misi tersebut maka perlu dilihat, konsistenkah kebijakan pemerintah dibawah komando Presiden Jokowi untuk mendukung KPK, sebagai symbol pemberantasan nasional.

Secara konseptual strategi pemberantasan korupsi harus dibangun dan didahului oleh adanya itikad kolektif, yaitu semacam kemauan dan kesungguhan (willingness) dari kekuasaan Presiden tidak memberikan toleransi sedikitpun terhadap perilaku korupsi. Oleh karena itu, dalam mewujudkan sebuah strategi yang efektif memberantas korupsi, dibutuhkan pemenuhan prasyarat yakni didorong oleh political will yang kuat (Badjuri, 2011). Hal tersebut dilakukan dengan memberikan dukungan politik yang jelas dan tegas, diberikan oleh Presiden terhadap lembaga KPK. Sikap politik Presiden yang demikian, sesungguhnya menjadi kunci keberhasilan strategi pemberantasan korupsi. Sebaliknya sikap politik yang tidak berpihak pada kelembagaan KPK dapat merusak cita-cita pemberantasan korupsi. Maka sangat penting untuk melihat sejauh mana kebijakan Presiden Jokowi yang mendukung kelembagaan KPK, dalam arti sudahkah terlaksana dengan baik political will presiden jokowi terhadap KPK.

Kita ketahui bersama Sejak tahun 2018 hingga 2021 political will Presiden Jokowi terhadap kelembagaan KPK kerap dipertanyakan. Ada tiga persoalan konkrit yang penulis ambil sebagai bahan kajian untuk menilai sejauh mana political will Presiden Jokowi terhadap kelembagaan KPK. Tiga persoalan ini juga menimbulkan pertanyaan ditengah publik, perihal seriuskah Presiden Jokowi mendukung kiprah KPK. Pertama, Lambannya penemuan fakta dibalik penyiraman air keras terhadap mata 
Novel Baswedan penyidik senior KPK. Kedua, Surat Presiden yang dikirim ke DPR menandakan pembahasan revisi Undang-Undang 30/2002. Ketiga, Arahan Presiden soal pertimbangan ulang penon-aktifan 51 pegawai KPK di abaikan oleh pimpinan KPK. Tiga persoalan ini menjadi pilihan penulis untuk melihat sejauh mana political will Presiden Jokowi terhadap kelembagaan KPK.

Perjalanan kelembagaan KPK dalam treck recordnya, selalu diwarnai integritas. sulit untuk membantah bahwa KPK dianggap sebagai lembaga pemberantaskorupsi paling berhasil sepanjang republik berdiri (Ramadhana, 2019).

\section{Metode Penelitian}

Metode penelitian hukum yang digunakan dalam penelitian ini adalah metode penelitian yuridis-normatif. Yakni hukum dikonsepkan sebagai apa yang tertulis dalam peraturan perundang-undangan (law in books) atau hukum dikonsepkan sebagai kaidah atau norma yang merupakan patokan berperilaku manusia yang dianggap pantas (Badjuri, 2011). Penelitian hukum normatif ini didasarkan kepada bahan hukum primer dan sekunder, yaitu penelitian yang mengacu kepada norma-norma yang terdapat dalam peraturan perundang-undangan. Metode penelitian yuridis normatif ini akan mengkaji tentang political will terhadap kelembagaan KPK era Presiden Jokowi. Kemudian Menemukan dan memformulasikan keharusan politicall will Presiden Jokowi terhadap keberlangsungan kelembagaan KPK.

\section{Hasil dan Pembahasan}

\section{Politicall Will Terhadap Kelembagaan KPK Era Presiden Jokowi}

Dalam ilmu politik, gagasan arus utama pemberantasan korupsi dikembangkan dari teori principal-agent. Teori ini melihat korupsi sebagai pengkhianatan agen terhadap mandat yang telah diberikan oleh principal. Dalam korupsi politik, korupsi oleh politisi atau agenmerupakan pengkhianatan politisi terhadap rakyat sebagai principal yang telah memberikan mandat dalam Pemilu. Dalam korupsi birokrasi, korupsi oleh pegawai negeri merupakan pengkhianatan terhadap mandat yang telah diberikan oleh pemimpin instansi pemerintah Presiden (Johanes Danang Widoyoko, 2016). Sehingga presiden sudah sewajarnya dan sepatutnya berperan memperbaiki masa depan pemberantasan korupsi.

Sahre J. Kpudeh mengartikan kemauan politik sebagai "niatan kredibel langsung dari aktor politik untuk memerangi penyebab dan akibat dari korupsi di level sistemik" (Quah, 2003). Korupsi yang sistemik tidak saja terjadi pada aktivitas mengambil uang negara. Lebih dari itu menyerang kelembagaan dan personal anggota kelembagaan pemberantasan korupsi juga merupakan rangkaian melakukan korupsi (Kurniawan, 2019). nilah yang terjadi di Indonesia, serangan koruptor tidak saja di alamatkan terhadap lembaga seperti KPK, namun juga personil lembaganya. Upaya pelemahan terhadap pemberantasan korupsi di Indonesia, dilakukan mulai dari menyerang kelembagaan melalui upaya legislasi dengan melemahkan KPK, sampai dengan menyerang penyidik senior KPK novel baswedan. 
Penyidik Senior Komisi Pemberantasan Korupsi (KPK) Novel Baswedan meminta Presiden Joko Widodo (Jokowi) segera menyelesaikan kasus penyerangan air keras terhadapnya. Novel meminta Jokowi merealisasikan janjinya untuk mengungkap siapa pelaku utama dibalik penyiraman air keras yang menyebabkan matanya menjadi tidak normal.

Permintaan novel terhadap Presiden Jokowi sangatlah berdasar. Sebab jika melihat Undang-Undang Nomor 2 Tahun 2002 Tentang Kepolisian Negara Republik Indonesia Pasal 8 menyebutkan:

1. Kepolisian Negara Republik Indonesia berada di bawah Presiden;

2. Kepolisian Negara Republik Indonesia dipimpin oleh Kapolri yang dalam pelaksanaan tugasnya bertanggung jawab kepada Presiden sesuai dengan peraturan perundang-undangan.

Maka mekanisme atasan dan bawahan sangat dimungkinkan antara Presiden dan Kepolisian. Berpijak pada teori pembagian kekuasaan dan sistem pemerintahan presidensil, fungsi pemerintahan diselenggarakan oleh lembaga eksekutif yang dipimpin oleh Presiden, sehingga Presiden bertanggungjawab atas penyelenggaraan pemerintahan. Oleh karena itu mengkaji tentang kedudukan kepolisian yang didasarkan pada fungsi utamanya, tidak dapat dipisahkan dengan fungsi utama pemerintah yang dipimpin oleh Presiden (Danendra, 2013). Tidak aneh jika Novel meminta Presiden untuk menyelesaikan kasusnya, karena Presiden membawahi Polri yang bertugas menuntaskan persoalan kasus kriminal.

Selain persoalan novel diatas, persoalan lain perihal political will Presiden Jokowi adalah saat masyarakat ramai-ramai menolak revisi Undang-Undang 30/2002 yang sekarang telah menjadi Undang-Undang 19/2019 tentang KPK. Presiden Jokowi tidak tampil sebagai kepala negara yang berpihak terhadap rakyat. Malahan yang terjadi Presiden Joko Widodo menandatangani dan mengirimkan Surat Presiden (SurPres) terkait revisi Undang-Undang Komisi Pemberantasan Korupsi kepada Dewan Perwakilan Rakyat. Dengan terbitnya surpres ini, pemerintah setuju untuk membahas revisi Undang-Undang KPK bersama DPR. Surpres berisi penjelasan dari Presiden, bahwa presiden telah menugaskan menteri untuk membahas revisi Undang-Undang KPK bersama DPR. Sebelumnya, semua fraksi di DPR setuju revisi Undang-Undang KPK yang diusulkan Badan Legislasi DPR. Persetujuan seluruh fraksi disampaikan dalam rapat paripurna DPR yang digelar pada Kamis 5 September 2019. Draf revisi langsung dikirim kepada Presiden Jokowi.

Sikap presiden jokowi mengirimkan surpres menimbulkan pertanyaan mendasar, mengapa bisa presiden menyetujui revisi Undang-Undang yang ditolak oleh masyarakat luas. Apakah presiden jokowi tunduk terhadap rakyat ataukah kekuasaan oligarki di DPR. Sebab dengan mengirimkan surpres maka Undang-Undang No. 19 Tahun 2019 Tentang Perubahan Undang-Undang No. 30 Tahun 2002 Tentang pemberantasan korupsi menjadi disahkan, yang dampaknya hingga saat ini sangat dirasakan jauh dari konsep hukum kelembagaan pemberantasan korupsi yang di idealkan (Wahyuningrum, Disemadi, \& Jaya, 2020). 
Padahal presiden punya waktu yang banyak untuk menolak pengesahan UndangUndang No 19 Tahun 2019 tersebut. Sebab dalam sistem ketatanegaraan Indonesia, Undang-Undang Dasar 1945 hasil amandemen, memberikan kekuasaan legislatif begitu besar kepada Presiden. Selain mempunyai kekuasaan membentuk undang-undang bersama DPR, dalam kondisi kegentingan yang memaksa Presiden juga mempunyai kekuasaan membentuk Peraturan Pemerintah Pengganti Undang-Undang (Perppu), serta berhak menetapkan Peraturan Pemerintah untuk menjalankan undang-undang (Ghoffar, 2019).

Sebagaimana yang telah dijelaskan diatas kekuasaan legislasi Presiden pasca reformasi begitu besar dan kuat. Presiden bukan saja sebagai pihak terkait atau pembahas, lebih dari itu Presiden menentukan sah atau tidaknya suatu Undang-Undang. Bahkan dalam hal Presiden ingin melakukan veto terhadap suatu Undang-Undang yang sudah berlaku dan sementara dijalankan. Presiden dapat menerbitkan Perppu yang membatalkan suatu Undang-Undang, dimana hak tersebut merupakan hak konstitusional seorang Presiden. Maka sudah sangat wajar jika masyarakat mempertanyakan political will Presiden Jokowi terhadap kelembagaan KPK. Pembelaan yang selama ini terjadi dalam beberapa era presiden, adalah dalam pengambilan keputusan presiden tidak sendiri ada DPR yang kepentingannya juga harus diakomodasi.

Secara politik, Indonesia memang merupakan negara yang menempatkan koalisi sebagai bagian kekuatan Partai Politik (Parpol) dalam pertarungan merebut kekuasaan pada pemilihan Presiden. Koalisi yang diciptakan diantara partai politik di Indonesia tidak kaku dan cenderung liquid/cair, dikarenakan koalisi lebih mengutamakan pada kesamaan kepentingan bersama dalam memperoleh kekuasaan. Kekuatan koalisi yang dibangun partai politik pada pemilihan Presiden berasal dari pada kekuatan penguasaan parlemen. Hal ini dilakukan oleh koalisi-koalisi dari masing-masing pendukung sehingga bukan hanya koalisi di ranah eksekutif namun legislatif juga diperkuat (Wospakrik, 2016).

Memang menjadi dilema, sebab system pemerintahan kita menjadikan siapapun menjadi Presiden akan cenderung bermuka dua. Disatu sisi harus menjaga suara masyarakat sebagai pemegang suara demokrasi yang sebenarnya. Namun disatu sisi Presiden juga harus mendengarkan suara politik di DPR. Karena jika engan mendengarkan maka Presiden dapat dijebak dalam pengambilan keputusan. Dalam kata lain Presiden dapat dipenjara dalam suatu pengambilan keputusan dengan kekuatan parlemen (DPR). Hanya saja jika seorang Presiden bersikap negarawan maka tentu dia tidak akan tunduk pada kepentingan oligarki di DPR.

Kemudian untuk melihat konsistensi political will presiden Jokowi dalam ranah dukungan terhadap personil kelembagaan KPK, dapat kita lihat dalam alih status pegawai KPK menjadi ASN. Presiden Jokowi telah memberikan pernyataan terkait tindak lanjut bagi 75 pegawai KPK yang dinyatakan tidak lulus dalam tes wawasan kebangsaan (TWK) sebagai proses pengalihan status menjadi Aparatur Sipil Negara (ASN). Dalam pernyataannya, Presiden memandang bahwa hasil TWK terhadap 
pegawai KPK hendaknya menjadi masukan untuk langkah-langkah perbaikan KPK, baik terhadap individu maupun institusi. Presiden Jokowi juga sependapat dengan pertimbangan Mahkamah Konstitusi (MK) dalam Putusan Pengujian Undang-Undang (Undang-Undang) Nomor 19 Tahun 2019 tentang Perubahan Kedua Undang-Undang KPK. Selain itu, menurutnya, proses pengalihan status pegawai KPK menjadi Aparatur Sipil Negara (ASN) tidak boleh merugikan hak pegawai KPK untuk diangkat menjadi ASN. Jokowi meminta kepada para pihak yang terkait, khususnya pimpinan KPK, Menteri PANRB, dan Kepala BKN untuk merancang tindak lanjut bagi 75 pegawai KPK yang dinyatakan tidak lulus tes, dengan prinsip-prinsip sebagaimana saya sampaikan tadi.

Instruksi Presiden Jokowi ini sama sekali tidak di indahkan, baik oleh KPK maupun kemenPAN-RB dan BKN sebagai pejabat yang melaksanakan proses seleksi. Padahal Presiden selain berfungsi sebagai kepala negara juga berfungsi sebagai kepala pemerintahan. Maka fungsi kepala pemerintahan sebenarnya sudah cukup memberikan jawaban, bahwa arahan Presiden Jokowi harus didengarkan dan tidak boleh jadi angin lalu. Padahal secara hierarki jabatan Presiden tentu merupakan kepala pemerintahan yang membawahi Menteri PANRB, BKN dan KPK. Presiden Jokowi harus mengambil alih, proses peralihan status ASN bagi pegawai KPK dengan membatalkan TWK yang diadakan tersebut.

Peraturan Pemerintah Republik Indonesia Nomor 17 Tahun 2020 Tentang Perubahan Atas Peraturan Pemerintah Nomor 17 Tahun 2017 Tentang Manajemen Pegawai Negeri Sipil pada pasal 3 ayat (7) menyebutkan: Pendelegasian kewenangan sebagaimana dimaksud pada ayat (2) dapat ditarik kembali oleh Presiden dalam hal:

a. Pelanggaran prinsip sistem merit yang dilakukan oleh PPK; atau

b. Untuk meningftatkan efektifitas penyelengaraan pemerintahan.

Artinya Presiden dapat mengambil alih mandat yang telah diberikan kepada Menteri PANRB, dan Kepala BKN sebagai pelaksana seleksi terhadap 51 pegawai KPK yang dinon-aktifkan. Presiden memegang peranan yang begitu penting dalam menyelamatkan 51 pegawai KPK yang diberhentikan dengan alasan tidak rasional. Mengapa tidak rasional? Sebab Undang-Undang No. 19 Tahun 2019 Tentang KPK, maupun PP nomor 41 tahun 2020 Tentang pengalihan pegawai komisi pemberantasan tindak pidana korupsi menjadi aparatur sipil negara sama sekali tidak mempersyaratkan pegawai KPK harus diseleksi untuk dapat dinyatakan bisa menjadi ASN atau tidak. Sehingga jelas sekali Presiden Jokowi memiliki peluang yang besar untuk membatalkan TWK yang diselenggarakan oleh KemenPANRB, BKN dan KPK.

Abdul Latif dan Hasbi Ali mengemukakan bahwa sesunggunya politik sebagai sumberdaya hukum. Menurutnya, ada tiga titik temu antara politik dan hukum di dalam kehidupan masyarakat. Pertama, pada waktu pengangkatan pejabat hukum, walaupun tidak semua proses pengangkatan pejabat hukum melibatkan politik, namun proses itu terbuka bagi keterlibatan politik; Kedua, proses pembuatan hukum itu sendiri, setiap proses pembuatan kebijaksanaan formal yang hasilnya tertuang dalam hukum pada dasarnya produk politik; dan Ketiga, proses pelaksanaan atau penegakan hukum (law 
enforcement), di mana pihak-pihak yang berkepetingan berusaha mempengaruhi pelaksanaan kebijaksanaan yang sudah berbentuk hukum, sejalan dengan kepentingan dan kekuatannya (Sahid, 2016).

Pendapat Abdul Latif dan Hasbi Ali diatas, memberikan penegasan bahwa penegakan hukum sebagai bagian dari proses hukum tidak dapat merdeka dari pengaruh politik. Sangat sulit bagi KPK berdiri diatas perjuangan pemberantasan korupsi yang dukungan politiknya krisis dan memprihatinkan. Harusnya KPK bukan lagi berada pada level mempersoalkan kewenangannya yang terseok-seok, bukan lagi pada fase mencari dukungan politik. Harusnya KPK sudah berada pada level membangun system pengelolaan negara yang bersih dan bebas dari korupsi, yang lazimnya dikenal dengan istilah zona integritas. Political will Presiden Jokowi sangat dibutuhkan, sebab sejarah dapat mencatat di era siapa KPK mengalami masa krisis dan kehancuran. Presiden Jokowi perlu mengingat dan merenungi, bahwa Kekuasaan politik yang dijalankan dengan tidak mendukung agenda pemberantasan korupsi akan menghasilkan pemerintahan dan pemimpin masyarakat yang tidak legitimate di mata publik (Setiadi, 2018).

\section{Keharusan Political Will Presiden Jokowi terhadap Kelembagaan KPK}

Setiap kepemimpinan pasti menempatkan pembangunan ekonomi sebagai pilar utama dalam pembangunan nasional. Disaat bersamaan penghambat pembangunan ekonomi juga terjadi, yakni korupsi. Korupsi menjadi kendala dalam menciptakan kesejahteraaan pembangunan. Korupsi menjadi kendala untuk bangsa ini mewujudkan tujuan Negara kita "memajukan kesejahteraan". Maka setiap rezim kekuasaan tidak pernah absen untuk selalu menaruh perhatian pembangunan hukumnya dalam ranah pemberantasan korupsi. Sehingga setiap rezim sebenarnya sangat membutuhkan kehadiran lembaga pemberantasan korupsi yang mampu memberantas korupsi secara cepat dan berintegritas. Begitupun sebaliknya, masa depan pemberantasan korupsi pula sangat ditentukan oleh komitmen, dorongan politik atau political will Presiden (Umam, 2019).

Mayoritas peneliti kajian antikorupsi kontemporer bersepakat bahwa korupsi merupakan penghambat laju pembangunan ekonomi. Karena itu, agar arus investasi asing bisa masuk ke pasar dalam negeri, maka kepastian hukum dan stabilitas sosial, politik dan keamanan menjadi syarat mutlak untuk dihadirkan. Sehingga konsistensi political will dalam melawan korupsi sangat dibutuhkan dalam rangka memerangi korupsi dan menciptakan efisiensi pelaksanaan pembangunan ekonomi yang menjadi agenda wajib dan utama setiap periodesasi kepemimpinan Presiden.

Untuk menghadirkan kepastian hukum dan pemberantasan korupsi yang efektif tersebut, lembaga-lembaga internasional seperti International Monetary Fund (IMF), United States of America International Development (USAID) hingga World Bank yang bermazhab neo-liberalisme acapkali menawarkan paket kebijakan struktural kepada Negara-Negara berkembang berupa resep demokratisasi, liberalisasi pasar dan juga reformasi kelembagaan. Secara teoritik, terdapat dua prinsip dasar 
demokrasi yang diyakini ampuh menjadi instrumen pemberantasan korupsi, dimana sistem demokrasi memberikan mekanisme dan prosedur yang jelas kepada rakyat untuk menuntut pertanggungjawaban (accountability) dan transparansi (transparency) dalam pemerintahan.

Masalah yang sangat serius terjadi di Indonesia saat ini adalah masalah korupsi. Korupsi telah menjadi penyakit yang muncul perlahan-lahan sebagai momok yang dapat membawa kehancuran bagi perekonomian Negara (I Wayan Yuda SatriaI Wayan SuardanaIda Bagus Surya Darmajaya, 2013). Ekonomi yang rapuh akan berdampak pada perjalanan demokrasi. Sebab stabilitas ekonomi akan sangat mempengaruhi stabilitas pertahanan dan keamanan. Tidak mungkin membangun demokrasi tanpa kenyamanan internal negara.

Demokrasi sejatinya mensyaratkan sistem check and balance dalam kekuasaan dan supremasi hukum. Selanjutnya, agar tidak terjadi 'perselingkuhan' antara kekuasaan politik dan kekuatan ekonomi yang berakibat pada anomali pasar dan sistem demokrasi, maka mazhab neo-liberal ini menekankan pentingnya liberalisasi pasar untuk menghilangkan praktik-praktik monopoli. Kemudian, setelah demokratisasi dan liberalisasi pasar dapat menyehatkan sistem politik dan ekonomi suatu Negara, upaya pemberantasan korupsi dapat dipercepat dengan reformasi kelembagaan dengan menghadirkan Undang-Undang Antikorupsi dan pembentukan lembaga-lembaga khusus antikorupsi seperti KPK. Dengan demikian, secara teoritik, semakin tinggi kualitas demokrasi dan pasar suatu Negara yang ditopang dengan mesin antikorupsi yang agresif, maka akan semakin efektif upaya pemberantasan korupsi. Berbeda dengan di Indoonesia yang komitmen politik terhadap kelembagaan KPK-nya lambat laun bergerak secara lambat dan tidak tentu arahnya. Utamanya saat memasuki kepemimpinan Presiden Jokowi, KPK harus menerima kenyataan untuk dilemahkan kewenangannya melalui pengesahan Undang-Undang 19/2019.

Political will dari pemimpin politik tertinggi dalam suatu Negara merupakan kunci kesuksesan sekaligus kegagalan dari lembaga pemberantasan korupsi. Misalnya Di era kepemimpinan Presiden Joko Widodo, KPK menghadapi roller coaster agenda pemberantasan korupsi. Berbagai ancaman yang menghadirkan ketidakpastian masa depan KPK, telah dilakukan oleh kekuatan eksternal maupun internal KPK. Hal itu berdampak signifikan pada efektivitas mesin antikorupsi KPK. Hanya saja entah mengapa kemudian justru Presiden Jokowi sendiri mendukung pembentukan Undang-Undang 19/2019 yang hari ini menjadikan KPK tidak efektif dalam memberantas korupsi. KPK dibuat berjuang sendiri tanpa adanya political will dari Presiden. Sebuah fakta yang menunjukan bahwa Presiden seakan tunduk pada kekuasaan koalisi yang dibentuknya sendiri.

Indonesia telah mendeklarasikan hukum sebagai panglima dalam denyut kehidupan ketatanegaraannya sebagaimana diatur dalam Undang-Undang Dasar Negara Republik Indonesia Tahun 1945 (Yulianto, 2020). Sebagai suatu hukum tertinggi, tentu presiden harus meletakkan hukum diatas kepentingan politik. Sebab refleksi ketaatan seorang presiden terhadap Undang-Undang Dasar 1945 menunjukan 
presiden sedang membangun peradaban ketaatan terhadap dunia hukum. Mendukung KPK untuk penegakan hukum adalah bentuk peradaban anti korupsi sedang di bangun oleh presiden Jokowi.

Presiden Jokowi dapat belajar dari filiphina yang pernah mengalami hal serupa seputar lemahnya kepemimpinan politik dalam mendukung lembaga pemberantasan korupsi. Di Filipina pada paruh 1983 mengalami krisis pemberantasan korupsi. Para pelaku korupsi ironisnya yang dapat dibawa ke Pengadilan sangat sedikit dari banyaknya pelaku korupsi. Proses hukum pemberantasan korupsi tidak menyentuh pimpinan tertinggi. Kendala lemahnya pemberantasan korupsi di Filipina tersebut terjadi pada proses penyidikan dan penuntutan, bukan pada ranah pengadilan. Kepolisian dan Kejaksaan di filphina tidak adil dalam melaksanan tugas pemberantasan korupsi. Hanya kalangan kecil yang tidak memiliki kekuasaan kuat yang biasanya dituntut. Pengadilan di Filipina sebenarnya bisa saja menghukum pelaku dari hulu hingga hilir yang melakukan korupsi secara sistemik sebagaimana yang menjadi keinginan publik Filipina untuk penegakan hukum yang adil. Hanya saja proses hukum sebelum masuk ketingkat pengadilan kerap kali penegak hukum pada tingkat Kepolisian dan Kejaksaan membiarkan pejabat elit yang memiliki kekuasaan besar tidak tersentuh untuk diproses hukum.

Pasca jatuhnya Kekuasaan Ferdinand Emmanuel Edralin Marcos Sr, dalam revolusi Filipina 1986. Kekuasaan transisi melakukan upaya pemberantasan korupsi secara sistemik dan universal. Langkah pertama, pemerintahan Filipina melakukan beberapa upaya yang dilakukan untuk menangulangi korupsi antara lain adalah melakukan apolitisasi secara positif terhadap biroktasi sejalan dengan perubahan pemerintahan di Fhilipina dan perubahan lainnya di dalam masyarakat. Kedua langkah yang dilakukan ialah memenuhi aspirasi desakan masyarakat yang direspon positif kekuasaan pemerintah Filipina dalam rangka membangun komitment yang tinggi dari pemimpin Negara Filipina untuk memerangi korupsi.

Langkah konkrit yang menunjukan pemerintah Filipina memiliki konsistensi political will ialah tingginya kemauan politik untuk melakukan perbaikan terhadap Undang-Undang lembaga pemberantasan korupsi, yang tujuannya memperkuat kewenangan dan independensi kelembagaan pemberantasan korupsi di filipina. Diantaranya membentuk secara lengkap undang-undang lembaga pemberantasan korupsi Filipina yang merupakan salah satu undang-undang yang paling komprehensif di mana pun di dunia. Political will tersebut tercermin secara berjamaah oleh semua pejabat tinggi Negara, terlebih kepala Negara di Filipina mendukung penuh undang-undang lembaga pemberantasan korupsi Filipina. Konsistensi political will pemerintahan Filipina hingga saat ini masih membekas dan diamalkan oleh segenap elite pemerintahan di filipina. Konsistensi political will menjadi kian penting ditengah hukum yang selalu digerogoti oleh keputusankeputusan politik yang terkadang tanpa pertimbangan argumentasi hukum memadai utamanya pada wilayah perubahan legislasi. 
Sejatinya Konsistensi political will terhadap kelembagaan KPK dapat membantu penyelenggaraan pemerintahan yang menjunjung tinggi asas good governence dan sekaligus juga menunjukan political will pemerintah hadir dalam membangun zona integritas. Secara konseptual kebijakan harus sesuai dengan norma serta ideologi sebuah bangsa yang telah disepakati bersama. Ideology tidak saja soal Pancasila, namun juga rasa keadilan dimasyarakat. Tidak ada satupun hasil survey ataupun penelitian yang menolak pendapat bahwa korupsi tidak mendapat tempat dihati masyarkat Indonesia, dalam arti semua bersepakat korupsi merupakan musuh bersama. Sehingga sangat relevan jika kita menyimpulkan KPK adalah wujud kebijaksaan pelaksanaan ideology bangsa Indonesia yang anti terhadap korupsi.

Kebijaksanaan legislasi kita terhadap kelembaagaan KPK seharusnya berpihak pada penguatan kewenangan pemberantasan korupsi. Menurut van Der Blies seperti dikutip Krisnayuda. Terdapat beberapa asas yang dapat digunakan sebagai tolok ukur apakah sebuah kebijakan atau aturan yang diterbitkan merupakan aturan atau kebijakan yang baik atau tidak: a) Asas tujuan yang jelas, bahwa sebuah kebijakan dalam berbagai bentuknya yang dikeluarkan pemerintah sebagai pembentuk regulasi, harus memiliki tujuan yang jelas harus tampak juga penjelasannya. Setiap pernyataan dan diksi yang digunakan harus diutarakan dan diungkapkan secara eksplisit. b) Asas urgensi adalah asas untuk menghindari kemungkinan dikeluarkannya suatu kebijkan dalam bentuk apapun yang sebenarnya tidak memiliki kegunaan atau tidak diperlukan. c) Asas kemungkinan pelaksanaan, asas ini berkaitan dengan kemungkinan untuk mengimplementasikan dan menegakkan aturan di dalam praktiknya (Krisnayuda, 2016).

Olehnya itu sudah seharusnya Presiden Jokowi hadir dalam menyelesaikan persoalan yang sedang menimpa KPK. Tidak hanya cukup dengan menyapaikan pidato kenegaraan, lebih dari itu Presiden harus tampil dengan tindakan hukum. Yakni mengenai kasus novel, Presiden dapat mengintervensi Kapolri untuk bertindak secara cepat mengungkap fakta sebenarnya dibalik penyiraman air keras yang menyebabkan mata penyidik senior KPK novel baswedan menjadi tidak normal.

Mengenai Undang-Undang KPK Presiden dapat menerbitkan perppu KPK, membangun komunikasi dengan koalisi di DPR untuk menerima perppu yang isinya adalah mengembalikan marwah KPK seperti dalam Undang-Undang 30 Tahun 2002. Kemudian untuk TWK Presiden harus membatalkan TWK yang diselenggarakan KemenPANRB, BKN dan KPK.

Presiden harus mendukung KPK dari segala upaya politisasi yang bertujuan melemahkan KPK. Sebab KPK merupakan satu-satunya lembaga penegakan hukum yang dapat berfungsi secara optimal, intensif, efektif, profesional, dan berkesinambungan dalam pemberantasan tindak pidana korupsi bagi para koruptor khususnya di Indonesia. Sebagaimana telah diputuskan oleh Perserikatan BangsaBangsa (PBB) melalui suatu konvensi yang disebut The UN Convention Against 
Corruption tahun 2003, dimana Indonesia menjadi negara ke-48 yang meratifikasi konvensi ini pada Maret tahun 2006 (Ridho, 2019).

Masyarakat Indonesia bahkan dunia terus menyoroti upaya Indonesia dalam mencegah dan memberantas korupsi. Masyarakat dan bangsa Indonesia harus mengakui, bahwa hal tersebut merupakan sebuah prestasi, dan juga harus jujur mengatakan, bahwa prestasi tersebut, tidak terlepas dari kiprah KPK sebagai lokomotif pemberantasan dan pencegahan korupsi di Indonesia, yang didukung oleh masyarakat dan LSM, walaupun dampaknya masih terlalu kecil, tapi tetap kita harus berterima kasih dan bersyukur (Rahmanul \& Adianto, 2020).

Beban KPK dari waktu ke waktu semakin berat, berbagai tantangan internal danexsternal bersiap untuk mengadang kerja pemberantasan korupsi15, tantangan tersebut diantaranya: (Wawan Fransisco, 2020) a. Konsolidasi oligarkhi, desentralisasi actor \& wilayah korupsi;b. Tebang pilih dalam penanganan kasus korupsi. Revisi Undang-Undang KPK;d. Presiden yang tidak berpihak keapda KPK dan upaya pemberantasan korupsi;e. Korupsi politik oleh oligarki nasional dan local; f. Aparat penegak hukum yangmasih korup; g. Pembentukan hak angket yang bertujuan untuk menghambat kinerjaKPK;f. Memasukkan orang-orang bermasalah kedalam instansi KPK

\section{Kesimpulan}

Setelah menganalisis dan menguraikan dua rumusan masalah pada pembahasan diatas, maka dapat kita simpulkan, Political will Presiden Jokowi terhadap kelembagaan KPK masih menyimpan berbagai persoalan. Presiden belum tampil sebagaimana seharusnya seorang Presiden yang mencita-citakan pemberantasan korupsi. Seharusnya sikap political will yang baik dari Presiden Jokowi terhadap kelembagaan KPK tidak hanya dengan stagment semata. Sebab seorang kepala pemerintahan tindakan konkritnya adalah dalam bentuk suatu regeling (pengaturan) dan beshikking (keputusan). Dua hal inilah yang dapat mengukur apakah Presiden Jokowi memiliki political will terhadap kelembagaan KPK. Ataukah political will tersebut masih jauh dari yang dicita-citakan. 


\section{BIBLIOGRAFI}

Badjuri, Achmad. (2011). Peranan Komisi Pemberantasan Korupsi (KPK) sebagai lembaga anti korupsi di indonesia. Jurnal Bisnis Dan Ekonomi, 18(1).Google Scholar

Damanik, Khairul Ikhwan, Lubis, Elfian, Siregar, Tikwan Raya, Nilasari, Ivo, Khairuddin, Ahmad, Mufti, Norpan, Siswoyo, Gudo, \& Ningsih, Sutra. (2010). Otonomi Daerah, Etnonasionalisme, dan Masa Depan Indonesia: Berapa Persen Lagi Tanah dan Air Nusantara Milik Rakyat. Yayasan Pustaka Obor Indonesia. Google Scholar

Danendra, Ida Bagus Kade. (2013). Kedudukan dan Fungsi Kepolisian dalam Struktur Organisasi Negara Republik Indonesia. Lex Crimen, 1(4). Google Scholar

Fariz, Donal. (2019). Pemerintahan Joko Widodo dan Serangan Politik Terhadap KPK. Integritas: Jurnal Antikorupsi, 5(2), 19-33. Google Scholar

Ghoffar, Abdul. (2019). Perbandingan kekuasaan presiden Indonesia setelah perubahan UUD 1945 dengan delapan negara maju.Kencana:Jakarta. Google Scholar

https:// www. merdeka. com/ peristiwa/ jelang- pilpres- 2019 - novel- baswedan - tagih - janji- jokowi-selesaikan-kasusnya.html, dikutip 7 Juni 2021

https://nasional.kompas.com/read/2019/09/11/19372191/setujui-pembahasan-revisi-uukpk-jokowi-sudah-kirim-surpres-ke-dpr, dikutip 7 Juni 2021.

https://www.kompas.tv/article/174758/sikap-75-pegawai-kpk-terhadap-pernyataanpresiden-jokowi-soal-status-penonaktifan-dan-twk, dikutip 7 juni 2021.

I Wayan Yuda SatriaI Wayan SuardanaIda Bagus Surya Darmajaya. (2013). Kewenangan Komisi Pemberantasan Korupsi (KPK) Dalam Upaya Pemberantasan Tindak Pidana Korupsidi Indonesia. Journal Ilmu Hukum Kertha Semaya, 1(1), 1.

Johanes Danang Widoyoko. (2016). Menimbang Peluang Jokowi Memberantas Korupsi: Catatan untuk Gerakan Anti Korupsi. Jurnal Integritas, 2(1), 4. Google Scholar

Krisnayuda, Backy. (2016). Pancasila \& Undang-Undang" Relasi dan Transformasi Keduanya Dalam Sistem Ketatanegaraan Indonesia. Jakarta: Kencana. Google Scholar

Kurniawan, Kukuh Dwi. (2019). Gagasan Advokat Menjadi Whistleblower dalam Pengungkapan Tindak Pidana Korupsi. Justtia Jurnal Hukum, 3(1), 100-115. Google Scholar 
Nomenklatur visi-misi Jokowi-JK ditahun 2014. (2014)

Quah, Jon S. T. (2003). Singapore's anti-corruption strategy: is this form of governance transferable to other Asian countries? In Corruption and governance in Asia (pp. 180-197). Springer. Google Scholar

Rahmanul, Rahmanul, \& Adianto, Adianto. (2020). Peran KPK dalam Menangani Kasus Korupsi di Indonesia. FisiPublik: Jurnal Ilmu Sosial Dan Politik, 5(1), 2838. Google Scholar

Ramadhana, Kurnia. (2019). Menyoal Kinerja KPK: Antara Harapan dan Pencapaian. Integritas: Jurnal Antikorupsi, 5(2), 151-163. Google Scholar

Ridho, M. Zainor. (2019). Kpk Dan Kekuasaan. Al Qisthas: Jurnal Hukum Dan Politik Ketatanegaraan, 8(1), 19-59. Google Scholar

Sahid, Asep Abdul. (2016). Konflik Kpk Vs Polri Jilid Iii: Kontestasi Kuasa Dalam Penegakan Hukum Di Indonesia. Asy-Syari'ah, 18(1), 139-148. Google Scholar

Setiadi, Wicipto. (2018). Korupsi Di Indonesia Penyebab, Hambatan, Solusi dan Regulasi. Jurnal Legislasi Indonesia, 15(3), 249-262. Google Scholar

Umam, Ahmad Khoirul. (2019). Lemahnya Komitmen Antikorupsi Presiden di tengah Ekspektasi Pembangunan Ekonomi dan Tekanan Oligarki. Integritas: Jurnal Antikorupsi, 5(2), 1-17. Google Scholar

Wahyuningrum, Kartika Sasi, Disemadi, Hari Sutra, \& Jaya, Nyoman Serikat Putra. (2020). Independensi Komisi Pemberantasan Korupsi: Benarkah Ada? Refleksi Hukum: Jurnal Ilmu Hukum, 4(2), 239-258. Google Scholar

Waluyo, Bambang. (2017). Optimalisasi pemberantasan korupsi di indonesia. Jurnal Yuridis, 1(2), 162-169. Google Scholar

Wawan Fransisco. (2020). Pimpinan Komisi Pemberantasan Korupsi,Kebijakan Dan Tantangan Penanggulangan Korupsi Di Era 4.0. Jurnal Hukum Samudra Keadilan, 15(1), 41.

Wospakrik, Decky. (2016). Koalisi Partai Politik Dalam Sistem Presidensil Di Indonesia. Papua Law Journal, 1(1), 142-161. Google Scholar

Yulianto, Yulianto. (2020). Politik hukum revisi undang-undang KPK yang melemahkan pemberantasan korupsi. Jurnal Cakrawala Hukum, 11(1), 111-124. Google Scholar 
Muhammad Ilham Akbar

Yuwanto, Listyo. (2016). Kinerja Penanganan Tindak Pidana Korupsi Sumber Daya Alam dan Kepercayaan Terhadap Komisi Pemberantasan Korupsi. Integritas: Jurnal Antikorupsi, 2(1), 25-41. Google Scholar

Copyright holder :

Muh. Ilham Akbar (2021)

First publication right :

Jurnal Syntax Idea

This article is licensed under:

(c) $\bigoplus \ominus_{\mathrm{BY}}$ 